\title{
Maps and Illustrations
}

Maps

Penang Island, circa 2000

Southeast Asia and southern China

The Straits Settlements in the nineteenth century

George Town, 1807-8

Penang Island site locations, circa 2003

\section{Illustrations}

The Kong Hok Palace decorated to celebrate the coronation of a British king, possibly that of George V in 1911 iii

$\begin{array}{ll}\text { Stone inscription at Kek Lok Si } & 13\end{array}$

The Kong Hok Palace and the Chinese Town Hall before 1928

Decorated chingay float honoring Guanyin, $1928 \quad 31$

Picture postcard of the Pagoda of Ten Thousand Buddhas at

Kek Lok Si, 1930 s

Kek Lok Si in 2001

St. George's Anglican Church

Stone lion and George Town resident at the Kong Hok Palace

Altar to the Lord of Heaven, Ayer Itam 144

Tua Pek Kong procession, Ayer Itam 150

Graves of Tua Pek Kong and his sworn brothers, Sea Pearl Island $\begin{array}{ll}\text { Temple } & 151\end{array}$

The entry to the Tua Pek Kong Temple on Armenian Street 153 
xii / Maps and Illustrations

$\begin{array}{ll}\text { Roadside offerings to the wandering ghosts } & 161\end{array}$

The King of Hell and his four assistants 163

Emblem of the Universal Ferry (Central Primordial) Committee $\quad 167$

Hungry Ghosts Festival banquet in Ayer Itam market $\quad 170$

New Penang Chinese Town Hall 174

Contemporary chingay procession at Pesta Pulau Pinang 177

Possessed spirit medium in procession, Nine Emperor Gods Festival $\quad 184$

Possessed spirit medium cuts his tongue for blood for charms,

Nine Emperor Gods Festival 194

Image of Nazha, the Baby God, at a Nine Emperor Gods temple 197

Spirit medium performing fire ceremony 199

Spirit medium leads worshipers through the Southern God Peace Pass 201

Sending off the boat at the conclusion of the Nine Emperor Gods

$\begin{array}{ll}\text { Festival } & 202\end{array}$

$\begin{array}{ll}\text { The Three Religions Bushel Lamp } & 205\end{array}$ 